\title{
KNJIŽNICE I APLIKACIJE ZA PAMETNE TELEFONE
}

\section{LIBRARIES AND APPLICATIONS FOR SMARTPHONES}

\author{
Petar Lukačić \\ Gradska knjižnica i čitaonica „Fran Galovićc“ \\ petar@knjiznica-koprivnica.hr
}

UDK / UDC: 021:621.395.721.5:004

Stručni rad / Professional paper

Primljeno / Received: 19. 1. 2021.

Prihvaćeno /Accepted: 26. 10. 2021.

\section{Sažetak}

Cilj: U ovom radu nastoji se ukazati na mogućnosti korištenja pametnih telefona $\mathrm{u}$ praksi s posebnim osvrtom na postojeće hrvatske knjižnične aplikacije.

Metodologija: Rad se zasniva na pregledu literature i dosadašnjih postignuća u uvođenju pametnih telefona u poslovanje hrvatskih narodnih knjižnica.

Rezultati: Činjenicu da su pametni telefoni postali važan čimbenik naše svakodnevnice potvrđuje istraživanje koje je proveo Ipsos 2018. godine za Huawei a u kojemu se navodi da 70\% ispitanika nosi pametni telefon sa sobom čak i kad na kratko izlazi iz stana. ${ }^{1}$ Digitalni svijet nas obavija i uzima sve veći dio naših života, a knjižničare sve više usmjerava da u svakodnevnom radu koriste mogućnosti digitalnih tehnologija kako bi korisnicima pružili što kvalitetniju uslugu. Knjižničarska parola „biti tamo gdje su i korisnici“" odnosi se svakako i na pametne telefone.

Društveni značaj: Ovim se radom ukazuje na prednosti pametnih telefona u pružanju novih usluga korisnicima hrvatskih narodnih knjižnica.

Originalnost: U hrvatskoj knjižničarskoj literaturi nisu dosad na jednom mjesto okupljene informacije o pametnim telefonima i njihovoj primjeni u hrvatskim narodnim knjižnicama.

Ključne riječi: aplikacije, knjižnične aplikacije, pametni telefoni, mKnjižnica

1 Jesmo li ovisni? Više od polovice Hrvata nosi mobitel i u krevet. [citirano: 2021-01-15] Dostupno na: https://www.vecernji.hr/techsci/istrazivanje-mobitel-huawei-ipsos-1224345. 


\section{Abstract}

Goal: The paper seeks to point out and discuss the possibilities of using smartphones in libraries, with special reference to the existing Croatian library applications.

Methodology: The research is based on literature review and an overview of the achievements in the use of smartphones in Croatian public libraries.

Results: The fact that smartphones have become an important factor in our everyday lives was recently confirmed by a survey conducted by Ipsos in 2018 for Huawei which states that $70 \%$ of respondents take their smartphones with them even when they briefly leave their apartments. The digital world is enveloping us and is taking an increasing part of our days and lives, so the librarians are also making more and more use of the possibilities of digital technologies in their daily work in order to provide the highest quality service to their patrons. The librarians" slogan "to be where the users are" certainly applies to smartphones and mobile library services. In this paper, we try to briefly discuss the possibilities of using smartphones in practice, with special reference to the existing Croatian library applications.

Social significance: The author points out the advantages of smartphones in offering new services to users of Croatian public libraries.

Originality: Prior to this paper, there have not been papers in Croatian professional literature presenting in one place a systematic review of smartphones and their use in public libraries.

Keywords: applications, library applications, smartphones, mKnjižnica

\section{Uvod}

While considering the mobile context in which your users may connect is an important part of the planning behind a mobile offering, it is also important to have tempered expectations. In particular for newer technologies for which the world has very high hopes, it can be easy to get swept up in the excitement, and to deliver almost any nominal solution in order not to be seen as falling behind.

Bruce Washburn „Library Mobile Applications: What Counts as Success?“

Najvažniji vid poslovanja svake knjižnice njezini su korisnici. Svaki napor koji se ulaže u obnovu ili rekonstrukciju ili određeni program uzaludan je ako nije ciljano usmjeren na dobrobit korisnika te ga korisnici ne prepoznaju kao pozitivan napor. Tko je današnji korisnik knjižnice? Je li to samo korisnik koji fizički posjećuje prostor da bi zadovoljio vlastitu informacijsku potrebu? Je li fizički prostor knjižnice jedini „prostor“ o kojemu knjižničar treba voditi brigu? Korisnik 21. stoljeća je i onaj korisnik koji koristi usluge knjižnice i u digitalnom okruženju te konzumira sadržaje koje knjižničari stvaraju da bi mu olakšali pristup fizičkoj 
ili digitalnoj građi o kojoj skrbe. Korisnik 21. stoljeća u svojem svakodnevnom životu koristi svoj pametni telefon kako bi pristupio mrežnim stranicama knjižnice i koristio usluge koje knjižnica tamo nudi ili pronašao potrebnu informaciju. Broj pristupa mrežnim stranicama knjižnica pametnim telefonima ${ }^{2}$ svake godine raste i u ovom trenutku čini više od $50 \%$ internetskog prometa. No obraćaju li sve knjižnice pozornost i prilagođavaju svoju digitalnu prisutnost tim trendovima? Obraćaju li pozornost na takve potrebe svojih korisnika?

Suvišno je napominjati da je na poslovanje knjižnica uvelike utjecala informacijsko-komunikacijska tehnologija ${ }^{3}$ i to uglavnom pozitivno, olakšavajući knjižničarima odašiljanje informacija o građi, događanjima i raznim uslugama putem raznih kanala (e-kataloga, mrežnih stranica, društvenih mreža i slično) kako bi došli do korisnika, ali i zadovoljili njihove potrebe koje se razvijaju u skladu s vremenom u kojemu knjižnica djeluje. Među raznim varijacijama i mogućnostima današnjeg digitalnog okruženja pametni telefoni, točnije mobilne aplikacije, postali su još jedna od tehnologija koju knjižničari koristite kako bi se približili svojim korisnicima i time im olakšali svakodnevni život. U kontekstu teme ovog članka to primjećuju i korisnici koji cijene napore knjižničara, što potvrđuju rezultati dosadašnjih istraživanja, ${ }^{4}$ koji jasno naznačuju da su korisnici zadovoljni time što knjižničari koriste nove tehnologije kako bi obogatili svoje usluge. S padom cijena pametnih telefona i činjenicom da danas, prema najnovijoj svjetskoj statistici, ${ }^{5} 48,53 \%$ svjetske populacije posjeduje pametni telefon, tržište aplikacija raste, a knjižnice postaju dio tog tržišta i pronalaze svoje mjesto na pametnim telefonima svojih korisnika. Upravo su navedene okolnosti potaknule pisanje rada kojemu je osnovni cilj i namjena poticanje rasprave u hrvatskoj knjižničarskoj profesiji o prednostima i nedostacima knjižničnih mobilnih aplikacija te aktivnije sudjelovanje u njihovu razvoju.

\section{Pojam i vrste mobilnih aplikacija}

Dugo je termin ,aplikacija“ jednostavno smatran računalnim programom. Do promjene u poimanju pojma ,aplikacija“ dolazi u vrijeme kada je Apple razvio prvi iPhone, pa se pod aplikacijom uobičajeno razumijeva aplikacija koja se koristi

2 Usp. Clement, J. Share of global mobile website traffic 2015-2020. // Statista, 28 April, 2021. [citirano: 2021-01-15]. Dostupno na: https://www.statista.com/statistics/277125/share-of-website-traffic-coming-from-mobile-devices.

3 Usp. Qualitative research into the provision and impact of ICT in public libraries in Sweden. [citirano: 2021-01-15]. Dostupno na: https://digital.lib.washington.edu/researchworks/bitstream/ handle/1773/24036/TNS_Sweden_English.pdf?sequence=1.

4 Usp. Wang, C.; H. Ke; W. Lu. Design and performance evaluation of mobile web services in libraries: A Case study of the Oriental Institute of Technology Library. // The Electronic Library 30(2012), str. 33-50. DOI:10.1108/02640471211204051.

5 How many smartphones are in the world?: January 2021 mobile user statistics: discover the number of phones in the world \& smartphone penetration by country or region. [citirano: 202101-15]. Dostupno na: https://www.bankmycell.com/blog/how-many-phones-are-in-the-world. 
na pametnom telefonu ili tabletu. Mobilna aplikacija ${ }^{6}$ program je dizajniran za rad na mobilnom uređaju, kao što je pametni telefon ili prijenosno računalo. Mobilne aplikacije često služe kako bi korisnicima pružale slične usluge poput onih kojima inače pristupaju na osobnim ili prijenosnim računalima. Aplikacije su uglavnom male, individualne programske jedinice s ograničenim funkcijama. Prve aplikacije i mobilni operacijski sustav pod nazivom iOS $^{7}$ pustio je na tržište 2007. godine Apple $^{8}$ za svoje pametne telefone nazvane iPhone, prema viziji koju je imao Steve Jobs, a koja datira čak u 1983. godinu. Nakon Applea u izradu mobilnih aplikacija priključuje se i Google koji razvija Android ${ }^{9}$ operacijski sustav koji se na tržištu javlja 2008. godine. Danas u svijetu mobilnih operacijskih sustava iOS i Android najzastupljeniji su i dominiraju tim tržištem, ali Android prednjači pred iOS-om.

Za potrebe ovog članka mobilne aplikacije možemo podijeliti na četiri vrste: ${ }^{10}$ platformske (nativne) aplikacije, međuplatformske aplikacije, hibridne aplikacije i progresivne mrežne aplikacije.

Platformske (nativne) aplikacije imaju uvjerljivo najbolje performanse i izravan pristup svim dostupnim funkcionalnostima mobilnog uređaja. Ipak, takav način izrade aplikacije usmjerava ka stvaranju dviju odvojenih baza koda za svaku platformu (iOS i Android) te samim time čini razvoj aplikacije skupljim jer se radi o najmanje dvije aplikacije.

Međuplatformske aplikacije stvaraju se u više različitih programskih jezika i okvira, ali se nakon toga pretvaraju u nativnu aplikaciju koja se izravno oslanja na operativni sustav uređaja. Tako programeri razvijaju jednu aplikaciju u jednom kodu koji se može primijeniti na više platformi (iOs i Android). S obzirom na to da je kompatibilna s različitim operacijskim sustavima, razvoj takve aplikacije dopire do šire publike.

Hibridne aplikacije većim dijelom funkcioniraju na programskim jezicima koje programeri koriste za prikaz sadržaja na internetskom pretraživaču, tj. izrađuju se u kombinaciji HTML-a, ${ }^{11}$ CSS-a ${ }^{12}$ i JavaScripta. ${ }^{13}$ Ono što je vrlo praktično

\footnotetext{
6 Usp. Mobile application. // Cambridge Dictionary. [citirano: 2021-01-15]. Dostupno na: https://dictionary.cambridge.org/dictionary/english/mobile-application.

7 Usp. Wyatt Greg, Jr. History of iOS. Medium. [citirano: 2021-01-15]. Dostupno na: https:// gregwyattjr.medium.com/history-of-ios-b4948d4d7993.

8 Usp. The History of mobile apps. [citirano: 2021-01-15]. Dostupno na: https://inventionland. com/inventing/the-history-of-mobile-apps.

9 Usp. The history of Android: The evolution of the biggest mobile OS in the world. [citirano: 2021-01-15]. Dostupno na: https://www.androidauthority.com/history-android-os-name-789433.

10 Usp. What is mobile application development? [citirano: 2021-01-15]. Dostupno na: https:// aws.amazon.com/mobile/mobile-application-development.

11 Usp. HTML: Living Standard. [citirano: 2021-01-15]. Dostupno na: https://www.w3.org/TR/ html52/introduction.html\#background

12 Usp. CSS tutorial. [citirano: 2021-01-15]. Dostupno na: https://www.w3schools.com/css.

13 Usp. JavaScript. [citirano: 2021-01-15]. Dostupno na: https://developer.mozilla.org/en-US/docs/Web/JavaScript.
} 
jest to da većina programera ima iskustva rada s tim jezicima, ali smatra se da imaju niže performanse u odnosu na nativne i dosta ograničenu podršku nativnim značajkama pametnih uređaja.

Progresivne mrežne aplikacije novija su vrsta aplikacijskog programa isporučenog kroz internetski pretraživač, a izgrađuju se, kao i hibridne, kombiniranjem HTML-a, CSS-a i JavaScripta. Namijenjene su radu na bilo kojoj platformi koja koristi standardni pretraživač, ${ }^{14}$ uključujući stolna računala i pametne telefone. Mogli bismo čak reći da su progresivne mrežne aplikacije nadogradnja hibridnih aplikacija jer smanjuju prijašnji jaz u korisničkom iskustvu u kojem bolje iskustvo daju nativne aplikacije. U konačnici, to su aplikacije koje ne zahtijevaju instalaciju te postaju sve popularnije jer ne zauzimaju mnogo memorije pametnog telefona. Takve se aplikacije mogu pokretati izravno u pregledniku i dostupne su na početnom zaslonu. Razvoj takvih aplikacija puno je jeftiniji, troše manje prostora i podatkovnog prometa te se mogu pokretati na telefonima sa slabijim performansama. Naravno, takve aplikacije imaju ograničene funkcionalnosti, pa je ipak za potpun doživljaj potrebno izraditi pravu aplikaciju. ${ }^{15}$

\section{Kratak osvrt na pojavu prvih knjižničnih mobilnih aplikacija i istraživanja}

Prve znakove razvoja knjižničnih mobilnih aplikacija možemo pratiti u Sjedinjenim Američkim Državama vezano uz DC Public library ${ }^{16}$ za potrebe koje se 2009. godine razvija prva aplikacija namijenjena njezinim korisnicima. Uz pomoć te aplikacije mogao se pretraživati katalog, pročitati kratke anotacije o građi, provjeriti radno vrijeme ogranaka i njihove lokacije, ali i rezervirati knjižničnu građu. Ako se usporedi podatak da se prve mobilne aplikacije pojavljuju 2007. godine, moguće je zaključiti da je DC Public library promptno reagirala stvarajući tu aplikaciju i prepoznala trend razvoja novih usluga za svoje korisnike. Njezin primjer prihvaćaju i druge knjižice u SAD-u te se o razvoju i primjeni te i novih aplikacija počinje raspravljati sve češće unutar Američkog knjižničarskog društva. ${ }^{17}$ Osim samostalnog razvoja mobilnih aplikacija, knjižničari se okreću i gotovim rješenjima, pa tako istraživanje objavljeno u Library Journal iz 2018. godine na-

\footnotetext{
14 Usp. Microsoft Edge, Google Chrome, Mozzila Fireforx, Safari i slični.

15 Usp. Kuda idu mobilne aplikacije? [citirano: 2021-01-15]. Dostupno na: https://www.vecernji.hr/techsci/kuda-idu-mobilne-aplikacije-1347747.

16 Usp. DC Public Library launches first free library iPhone application in nation. // DC Public Library [citirano: 2021-01-15]. Dostupno na: https://www.dclibrary.org/node/574.

17 Usp. Vollmer, T. There's an app for that! Libraries and mobile technology: An Introduction to public policy considerations. // Policy brief 3(2010) [citirano: 2021-01-15]. Dostupno na: http:// www.ala.org/advocacy/sites/ala.org.advocacy/files/content/advleg/pp/pub/policy/mobiledevices. pdf.
} 
vodi da više od $32 \%$ američkih knjižnica koristi Boopsie ${ }^{18}$ kao platformu koja se prilagođava svakoj knjižnici i knjižničnom programu u kojemu knjižnica radi.

Knjižnične mobilne aplikacije ne pojavljuju se, naravno, samo u SAD-u. British Library ${ }^{19}$ izdaje svoju prvu aplikaciju 2011. godine, a slijede ih i druge zapadne zemlje koje počinju razvijati vlastite aplikacije.

Knjižničarima nije nedostajalo ideja kako iskoristiti taj novi vid komunikacije $\mathrm{s}$ korisnicima (od virtualnih šetnji, spajanja na kamere u knjižnici ili virtualnih izložbi). Uz postojeće, knjižničari su razvijali nove aplikacije, utemeljene na provedenim istraživanja među korisnicima o tome što bi im koristilo. U člancima koje su objavili Mansouri i Nooshin (2019), ${ }^{20}$ Kerr i Rasmussen Pennington (2017) ${ }^{21}$ i u istraživanju iz Library Journala ${ }^{22}$ moguće je pronaći objedinjene smjernice za kreiranje aplikacija koje bi pomogle knjižničarima i programerima u stvaranju kvalitetnijih aplikacija.

Kerr i Rasmussen Pennington (2017) proveli su istraživanje među osobama odgovornima za poslovanje škotskih narodnih knjižnicama, ali i među korisnicima knjižnica. Korisnici knjižnica u Škotskoj smatraju narodne knjižnice važnim dijelom zajednice, a autori u članku naglašavaju da je vrlo važno obratiti im se prilikom razvijanja aplikacija te ispitati njihovo mišljenje i potrebe. Svakako je zanimljiv podatak koji navode, a to je da 50 od 185 ispitanika nije znalo da njihova knjižnica ima aplikaciju, što navodi na zaključak da je potrebno provoditi smišljenu promidžbu. No, valja također istaknuti da je $84 \%$ korisnika koji koriste aplikaciju istaknulo da „redovito“ ili „,uvijek“ ostvare svoju potrebu prilikom korištenja iste, što pokazuje da je korist aplikacije visoka onima koji je koriste, te bi se to svakako odrazilo i na druge korisnike kad bi znali da aplikacija postoji.

Mansouri i Nooshin (2019) u svom radu ističu da su u početku istraživanja odabrali 53 aplikacije sveučilišnih i narodnih knjižnica, preuzeli ih na mobilni uređaj te od njih odabrali svega 15 aplikacija koje su zadovoljavale kriterije vrednovanja. Nakon proučavanja literature na temu aplikacija u knjižnicama i analize 15 aplikacija odabrali su 26 značajki koje bi svaka aplikacija trebala imati. Nakon toga proveli su istraživanje među korisnicima iz kojega su saznali da su zaduži-

18 Usp. Schwartz, M. Demco Buys Boopsie. [citirano: 2021-01-15]. Dostupno na: https://www. libraryjournal.com/?detailStory=demco-buys-boopsie.

19 Usp. British Library launches first smartphone app. [citirano: 2021-01-15]. Dostupno na: https://www.bl.uk/press-releases/2011/january/british-library-launches-first-smartphone-app\#.

20 Usp. Mansouri, A; N. A. Nooshin. Assessing mobile application components in providing library services. // The Electronic Library, 37, 1(2019), str. 49-66. DOI: 10.1108/EL-10-20180204.

21 Usp. Kerr, A.; D.R. Pennington. Public library mobile apps in Scotland: Views from the local authorities and the public. // Library Hi Tech 36, 2(2018), str. 237-251. DOI: 10.1108/LHT-052017-0091.

22 Usp. Public library mobile app survey: January 2018. [citirano: 2021-01-15]. Dostupno na: https://s3.amazonaws.com/WebVault/research/2018_PublicLibraryMobileAppSurvey.pdf. 
vanje i razduživanje, produženje posudbe, pretraživanje kataloga, „pitajte knjižničara" te radno vrijeme knjižnice, najvažnije značajke koje bi svaka aplikacija trebala imati. U zaključku naglašavaju da je važno da knjižničari razvijaju najbolje moguće aplikacije s najvišom kvalitetom pružanja usluga.

Navedena inozemna istraživanja pružaju dovoljno informacija knjižničarima da mogu prepoznati smjer u kojemu treba razvijati aplikacije i što je prioritet u razvoju.

Posebna kategorija svakako su aplikacije za čitanje $e$-knjiga i zvučnih knjiga, što je više izraženo u inozemstvu nego u Hrvatskoj. Stoga ne čudi da se u SAD-u pojavljuju mobilne aplikacije namijenjene čitanju $e$-knjiga i zvučnih knjiga iako se knjižničari susreću s problemima limitiranog opsega naslova zbog uvjeta koje određuju nakladnici, ${ }^{23}$ što dakako izaziva nezadovoljstvo i kod korisnika. U Hrvatskoj situacija nije ništa bolja unatoč početnom uzletu u produkciji $e$-knjiga 2012. godine. Zbog nedostatka kvalitetne distribucije $e$-knjiga do čitatelja putem knjižnica, može se reći da je produkcija $e$-nakladništva stala te se tek s pojavom aplikacija Biblos i ZaKi Book počela oporavljati. Elektroničko okruženje nudi brojne mogućnosti, ali profit često dirigira poslovne modele i načine distribucije $e$-knjiga i nakladnici često odlučuju ne objavljivati sve naslove i u elektroničkom obliku. $\mathrm{Na}$ to su učestalo ukazivale američke knjižnice i povremeno se sporile s nakladnicima. O početnoj i napetoj situaciji oko posudbe i ponude $e$-knjiga korisno je pročitati rezultate zanimljivog istraživanja PEW istraživačkog centra ${ }^{24}$ koje donosi kvalitetan i detaljan pregled situacije. No to je tema koja više zalazi u sferu $e$-knjiga nego knjižničnih mobilnih aplikacija te kao takva nije bitan dio ovog rada, ali ju je važno spomenuti jer se među prvim hrvatskim knjižničnim mobilnim aplikacijama javljaju upravo one koje nude mogućnost čitanja $e$-knjiga.

Za čitanje e-knjiga u SAD-u i Kanadi knjižnice najviše koriste aplikaciju Overdrive/Libby ${ }^{25}$ koju je razvila treća strana, ali je ciljano usmjerena na suradnju s knjižnicama i nakladnicima te se zadovoljstvo korisnika aplikacijom može vidjeti na Google Playu' ${ }^{26}$, gdje ju je više od 35000 osoba ocijenilo visokom ocjenom od 4,4, a na Apple Storeu ${ }^{27}$ više od 1,3 milijuna korisnika ocjenom 4,8. Tako

\footnotetext{
23 Usp. Pew Research Center. Part 6: A closer look at e-book borrowing: Overview of responses in our online panel. [citirano: 2021-01-15]. Dostupno na: https://www.pewresearch.org/internet/2012/06/22/part-6-a-closer-look-at-e-book-borrowing/\#librarians-and-publishers.

24 Usp. Pew Research Center. Part 1: An Introduction to the issues surrounding libraries and e-books. [citirano: 2021-01-15]. Dostupno na: https://www.pewresearch.org/internet/2012/06/22/ part-1-an-introduction-to-the-issues-surrounding-libraries-and-e-books.

25 Usp. Hi! I'm Libby. [citirano: 2021-01-15]. Dostupno na: https://www.overdrive.com/apps/ libby/

26 Usp. Libby, by OverDrive.// Google Play. [citirano: 2021-01-15].

Dostupno na: https://play.google.com/store/apps/details?id=com.overdrive.mobile.android.libby\&hl=en\&gl=US.

27 Usp. Libby, by OverDrive. // Apple Store. [citirano: 2021-01-15]. Dostupno na: https://apps. apple.com/us/app/libby-by-overdrive/id1076402606.
} 
visoke ocjene pokazuju da je aplikacija visoko sofisticirani proizvod utemeljen na iskustvu i višegodišnjem razvoju. Osim u SAD-u i Kanadi, Libby je pronašla svoje mjesto i kod korisnika u Singapuru, Njemačkoj, ali i drugim zemljama koje mogu financirati pristup njezinim sadržajima.

\section{Knjižnične mobilne aplikacije u Hrvatskoj ZaKi Book}

Aplikaciju ZaKi Book razvile su Knjižnice grada Zagreba u suradnji s tvrtkom VivaInfo te je predstavljena u svibnju 2019. godine, a korisnicima je omogućeno korištenje aplikacije od 31. svibnja 2019. Iako se na nekim mjestima navodi kao prva aplikacija za posudbu $e$-knjiga, ustvari se radi o prvoj aplikaciji za posudbu $e$-knjiga koju je razvila jedna hrvatska knjižnica. ${ }^{28}$ Aplikacija je prema osnovnom pregledu hibridna te koristi funkcionalnosti $e$-kataloga koji koriste korisnici knjižnica koje posluju u ZaKi sustavu.

Kod te aplikacije pohvalno je što se pri njezinom kreiranju razmišljalo i o raznim mogućnostima čitanja, pa je tako aplikacija napravljena za najpopularnije sustave iOS i Android, ali i za Windows platformu te je u prvim najavama napravljena i aplikacija za čitanje i na $e$-čitačima od $e$-tinte. Logično je zaključiti da korisnici najviše koriste aplikacije napravljene za Android, a zatim za iOS sustav, što se i može vidjeti prema broju preuzimanja aplikacija s Google Playa ${ }^{29}$ i Apple Storea.$^{30} \mathrm{Na}$ tim sustavima može se vidjeti i zadovoljstvo korisnika aplikacijom i njezinim mogućnostima.

Kada korisnik preuzme aplikaciju na svoj pametni telefon, prijavljuje se sa svojim korisničkim podacima koje je dobio u knjižnici. Aplikaciju mogu koristiti sve knjižnice, tj. korisnici knjižnica koje posluju u ZaKi sustavu te ona, u ovom trenu, nije prilagodljiva za korištenje korisnicima drugih knjižnica. Aplikacija je ista za sve korisnike ZaKi sustava.

\section{Biblos}

Kao i ZaKi Book aplikacija Biblos namijenjena je čitanju $e$-knjiga, a razvila ju je slovenska Beletrina, ${ }^{31}$ a na hrvatsko tržište dovele su je istarske knjižnice u su-

28 Usp. Prva hrvatska aplikacija za posudbu $e$-knjiga je TookBook eknjižnica koja je stupila na naše tržište prvo kao aplikacija za prodaju $e$-knjiga, a kasnije je izrađen poslovni model putem kojeg je korisnicima omogućena posudba $e$-knjiga.

${ }_{29}$ Usp. ZaKi Book. // Google Play. [citirano: 2021-01-15]. Dostupno na: https://play.google. $\mathrm{com} /$ store/apps/details?id=io.cordova.zakibook\&hl=hr.

30 Usp. ZaKi Book. // Apple Store. [citirano: 2021-01-15]. Dostupno na: https://apps.apple.com/ hr/app/zaki-book/id1464530319.

31 Usp. Beletrina. [citirano: 2021-01-15]. Dostupno na: https://beletrina.si. 
radnji s Beletrinom nakon što su prevele cijeli sustav sa slovenskog na hrvatski jezik. Sustav iBiblos predstavljen ${ }^{32}$ je u studenom 2018. godine te ga od tog trenutka koriste sve istarske narodne knjižnice, a od nedavno i Gradska i sveučilišna knjižnica Osijek ${ }^{33}$ svojim korisnicima nudi čitanje $e$-knjiga uz pomoć iste aplikacije.

Aplikacija je dostupna za najpopularnije operativne sustave Android i iOS, a odnedavno i za Huawei ${ }^{34}$ mobilne uređaje koji od prošle godine zbog problema $\mathrm{s}$ američkim vlastima počinju razvijati vlastito mjesto za preuzimanje aplikacija. Osim toga, pripremljena je i aplikacija za čitanje na $e$-čitačima na bazi $e$-tinte. Za razliku od ostalih knjižničnih aplikacija na hrvatskom tržištu, Biblos je prvi pripremio aplikaciju za Huawei mobitele te time pokazao kako pravodobno promišlja o svojim korisnicima. Zadovoljstvo korisnika kao i kod Zaki Book aplikacije lako se može iščitati u ocjenama i komentarima na Google Playu ${ }^{35}$ i Apple Storeu. ${ }^{36}$

Kao i kod ZaKi Booka korisnici se prijavljuju svojim korisničkim računom koji se potvrđuje u samoj knjižnici, a aplikacija je svima ista. Za razliku od ZaKi Booka koji mogu koristiti samo korisnici knjižnice koja posluje u ZaKi sustavu, aplikaciju Biblos mogu koristiti korisnici bilo koje knjižnice nevezano uz sustav u kojem knjižnica posluje, ${ }^{37}$ što je svakako prednost jer pokazuje otvoreniji poslovni model.

\section{Pozdrav iz Zagreba / Greetings from Zagreb / Advent in Zagreb}

Prva je aplikacija ${ }^{38}$ samostalno izrađena u Nacionalnoj i sveučilišnoj knjižnici u Zagrebu koja je time pokrenula izradu inovativnog digitalnog proizvoda koji povezuje turizam i kulturnu baštinu te promiče ljepote glavnog grada zabilježene na razglednicama. ${ }^{39}$ Namjena aplikacije je promidžba digitalizirane Grafičke zbirke

32 Usp. Predstavljena prva digitalna platforma za posudbu e-knjiga u Istri. [citirano: 2021-0115]. Dostupno na: https://www.pula.hr/hr/novosti/detail/18413/predstavljena-prva-digitalna-platforma-za-posudbu-e-knjiga-u-istri.

33 Usp. iBiblos - posudba elektroničkih knjiga za korisnike GISKO-a. [citirano: 2021-01-15]. Dostupno na: https://www.gskos.unios.hr/index.php/ibiblos-posudba-elektronickih-knjiga-za-korisnike-gisko-a.

34 Usp. Huawei AppGallery kao osnovna trgovina aplikacija? Upitali smo ih kako to funkcionira. [citirano: 2021-01-15]. Dostupno na: https://www.bug.hr/intervju/huawei-appgallery-kao-osnovna-trgovina-aplikacija-upitali-smo-ih-kako-to-15165.

35 Usp. Biblos2. // Google Play. [citirano: 2021-01-15]. Dostupno na: https://play.google.com/ store/apps/details?id=com.artatech.biblosReader\&hl=hr.

36 Usp. Biblos2. // Apple Store. [citirano: 2021-01-15]

Dostupno na: https://apps.apple.com/hr/app/biblos2/id1241880218.

37 Primjera radi - sve istarske knjižnice rade u ZaKi sustavu, dok Osijek posluje u Crolistu.

38 Usp. Zagreb bogatiji za još jednu mobilnu aplikaciju - Pozdrav iz Zagreba. [citirano: 202101-15]. Dostupno na: https://www.nacional.hr/zagreb-bogatiji-za-jos-jednu-mobilnu-aplikaciju-pozdrav-iz-zagreba.

39 Usp. Klarin Zadravec, S.; D. Koljenik. Pozdrav iz Zagreba: izložba. // Virtualne izložbe. [citirano: 2021-01-15]. Dostupno na: http://virtualna.nsk.hr/portfolio/pozdrav-iz-zagreba. 
pri Nacionalnoj i sveučilišnoj knjižnici, a s obzirom na činjenicu da je s vremenom promijenila nekoliko naziva i trenutno ima naziv Advent in Zagreb, moguće je pretpostaviti da su primarna ciljana skupina stranci.

Aplikacija je napravljena samo za Android ${ }^{40}$ sustav te osim starih razglednica Zagreba nudi i slanje i pregled božićnih razglednica.

Aplikaciju je za Nacionalnu i sveučilišnu knjižnicu izradila tvrtka Plava tvornica koja se specijalizirala za izradu mobilnih aplikacija. Osim tog projekta s Nacionalnom i sveučilišnom knjižnicom, napravljena je i aplikacija Pozdrav s Krke (Greetings from $\mathrm{Krka}$ ) koja bi spadala u istu kategoriju te se zato ne pribraja ovom popisu aplikacija.

\section{Smart Library NSK}

Kako navode na službenom mrežnom mjestu aplikacije, ${ }^{41}$ mobilna aplikacija Smart library NSK izrađena je u obliku Pametnog vodiča oslonjenog na beacone $e^{42}$ u prostoru Nacionalne i sveučilišne knjižnice u Zagrebu te virtualno povezuje korisnika i Knjižnicu. Aplikacija kontekstualizira prostor od 36478 kvadratnih metara te smisleno povezuje 22 lokacije s 22 usluge za više od 15000 korisnika. Kako bi aplikacija optimalno funkcionirala, potrebno je uključiti bluetooth i dati dopuštenje aplikaciji da pristupi lokaciji korisnika aplikacije.

Projektom se nastojao stvoriti temelj za razvoj Pametne knjižnice (Smart Library) kao dijela infrastrukture Interneta stvari (IoT). Cilj je istražiti mogućnosti primjene IoT-tehnologija u knjižnicama izradom prototipa mobilne aplikacije koja u obliku Pametnog vodiča oslonjenog na beacone u prostoru NSK-a, virtualno povezuje korisnika i knjižnicu. Osim što služi kao generator istraživanja primjene novih tehnologija u knjižnicama, otvara i nove mogućnosti za interdisciplinarna istraživanja koja obuhvaćaju suvremene načine interakcije korisnika s prostorom, građom i uslugama knjižnice.

Aplikacija osim navedenog nudi mogućnost korištenja više usluga NSK-a koje su kratkim opisima i poveznicama spojene s mrežnim mjestom knjižnice. Osim usluga, aplikacija povezuje vijesti i odabranu digitaliziranu građu iz bogatog fonda knjižnice. Aplikacija je zanimljiva kombinacija povezivanja mrežnih stranica knjižnice i same aplikacije, ali zbog slabije responzivnosti mrežnog mjesta, umanjuje brzinu i kvalitetu plasiranja informacija korisnicima. U usporedbi s ostalim aplikacijama ona jedina nudi najveći broj usluga knjižnice objedinjenih u jednoj aplikaciji.

\footnotetext{
40 Usp. Advent in Zagreb. // Google Play. [citirano: 2021-01-15]. Dostupno na: https://play. google.com/store/apps/details?id=com.pozdravizzagrebagmail.greetingsfromzagreb\&hl=en.

${ }^{41}$ Usp. Smart library NSK: Virtualni vodič kroz prostor i usluge Nacionalne i sveučilišne knjižnice u Zagrebu. [citirano: 2021-01-15]. Dostupno na: http://smart.nsk.hr.

42 Usp. Beaconi su low bluetooth uređaji koji omogućuju lociranje unutar prostora i odašiljanje poruka mobilnim uređajima koji se nađu u dometu uređaja.
} 


\section{e-Iskaznica}

Gradska knjižnica Poreč, prateći potrebe svojih članova, kroz informacijsko-tehnološki razvoj s ciljem osuvremenjivanja usluga, uvodi $e$-Iskaznicu ${ }^{43}$ za svoje korisnike koja je puštena u javnost početkom 2020. godine. Da bi se utvrdilo koje sve mogućnosti osim digitalne iskaznice aplikacija nudi, potrebna prijava u sustav. Aplikacija je izrađena za korisnike Android ${ }^{44}$ i iOS ${ }^{45}$ sustava.

\section{mKnjižnica}

Pojam mKnjižnica ${ }^{46}$ objedinjuje više aplikacija izrađenih za potrebe knjižničnog poslovanja. Radi se o prvoj aplikaciji izrađenoj za potrebe korisnika Knjižnice i čitaonice „Fran Galović“ Koprivnica koja je predstavljena u koprivničkoj knjižnici krajem 2019. godine ${ }^{47}$ pod nazivom Knjižnica Fran Galović. O samoj aplikaciji i njenim mogućnosti više informacija nalazi se u časopisu Svezak..$^{48} \mathrm{O}$ samoj aplikaciji potrebno je napomenuti da je prva takve vrste u Hrvatskoj koja je razvijena u samoj knjižnici s ciljem približavanja usluga koprivničke knjižnice njezinim korisnicima.

Za razliku od ranije navedenih aplikacija, ta aplikacija ima univerzalnu namjenu, a to je pružiti korisnicima knjižnice mogućnost ostvarivanja pristupa osnovnim uslugama koje knjižnice nude u svom poslovanju (pretraživanje $e$-kataloga, pregled događanja u knjižnici, digitalna iskaznica, produženje i rezervacija građe, slanje zahtjeva za pretraživanje literature, informacije o radnom vremenu i slično). Pritom su se mogućnosti birale na temelju nekoliko ranije spomenutih inozemnih istraživanja ${ }^{49}$ provedenih među korisnicima knjižnica i knjižničarima.

Nabrojene mogućnosti bitne su korisnicima svih knjižnica te su koprivnički knjižničari zaključili da aplikaciju ne trebaju ponuditi samo svojim korisnicima, već da bi i druge knjižnice i njihovi korisnici trebali imati istu takvu mogućnost.

43 Usp. E-iskaznica: Novi digitalni iskorak Gradske knjižnice Poreč. [citirano: 2021-01-15]. Dostupno na: https://www.knjiznicaporec.hr/e-usluge/e-iskaznica.

44 Usp. e-Iskaznica: Gradska knjižnica Poreč. // GooglePlay. [citirano: 2021-01-15]. Dostupno na: https://play.google.com/store/apps/details?id=hr.com.synet.eiskaznice\&hl=hr\&gl=US.

45 Usp. e-Iskaznica. // Apple Store. [citirano: 2021-01-15]. Dostupno na: https://apps.apple. com/us/app/eiskaznica/id1579065835\#?platform=iphone.

46 mKnjižnica. [citirano: 2021-01-15]. Dostupno na: www.mknjiznica.com.

47 Usp. Škoda, S. Knjižnica i čitaonica Fran Galović predstavila mobilnu aplikaciju, ravnatelj Galinec: Postajemo još dostupniji korisnicima. [citirano: 2021-01-15]. Dostupno na: https://drava.info/2019/12/knjiznica-i-citaonica-fran-galovic-mobilna-aplikacija.

48 Usp. Lukačić, P. Nativna aplikacija Knjižnica „Fran Galović“. // Svezak 22(2020), str. 11-13. [citirano: 2021-01-15]. Dostupno na: http://www.drustvo-knjiznicara-bpkp.hr/svezak/svezak22/ Svezak_22_2020.pdf.

49 Usp. Mansouri, A; N. A. Nooshin. Nav. dj., str. 49-66.; Kerr, A.; D.R. Pennington Nav. dj., str. 237-251. 
Zbog toga su krenuli u poduzetničke vode odlučivši se za drugačiji model poslovanja od onog koji su oblikovali vlasnici ZaKi Book i Biblos aplikacije - za svaku knjižnicu izrađuje se nova međuplatformska (nativna) aplikacija programirana u React Nativeu ${ }^{50}$ koja nema jedinstveno ime i više korisnika raznih knjižnica. Do trenutka pisanja ovog članka izrađeno je 15 aplikacija za narodne knjižnice ${ }^{51} \mathrm{u}$ Hrvatskoj za tri knjižnična sustava u kojima narodne knjižnice rade (Metel, Zaki i Crolist) jer je u planiranju izrade aplikacije cilj bio izraditi okvir koji je primjenjiv na specifične uvjete poslovanja hrvatskih knjižnica. Svaka izrađena aplikacija nosi naslov knjižnice kojoj je namijenjena, dok je naziv mKnjižnica samo naziv „,sustava“, točnije programskog rješenja koje objedinjuje sve aplikacije.

\section{Zaključak}

U ovome smo radu predstavili dostupne aplikacije za korisnike hrvatskih knjižnica koje smo razvrstali u tri skupine: one koje omogućuju čitanje $e$-knjiga (Biblos i ZaKi Book), one koje omogućuju pristup uslugama (e-Iskaznica i mKnjižnica) i one koje omogućuju pregled digitalizirane građe (Pozdrav iz Zagreba). Jedino aplikacija Smart Library NSK objedinjuje više mogućnosti, točnije putem nje korisnici mogu koristiti digitalne usluge knjižnice, ali i pristupiti digitaliziranoj građi knjižnice. Smjer u kojemu bi se aplikacije trebale razvijati svakako je da objedinjuju što više mogućnosti u jednoj aplikaciji kako se korisnike ne bi dovodilo u situaciju da preuzimaju više aplikacija za korištenje usluga jedne ustanove. Ako to nije moguće iz financijskih i kadrovskih razloga, u razvijanju aplikacija potrebno je što više olakšati korisničko iskustvo i pojednostaviti pristup mogućnostima aplikacije kako korisnici ne bi odustajali od korištenja. Razvoj aplikacija ili plaćanje licenci za korištenje novo je opterećenje na budžet knjižnice, stoga je prioritet omogućiti što bolje korisničko iskustvo te na tome ustrajati prilikom nabave aplikacije.

Trebalo je manje od 8 godina od pojave prve knjižnične mobilne aplikacije da u se u Hrvatskoj pojavi sličan proizvod koji bi svojim obilježjima slijedio svjetske trendove. Praćenje svjetskih knjižničarskih trendova tijekom 8 godina prihvatljivo je u okviru poslovanja knjižnica 20. stoljeća, ali u 21. stoljeću kad se informacije razmjenjuju digitalnim tehnologijama, 8 je godina predugo. To je predugo razdoblje da bi knjižnice opravdavale svoj status u društvu kao relevantan čimbenik u pružanju pristupa znanju i informacijama. Potrebno je na nacionalnoj razini naglasiti da hrvatske knjižnice i hrvatsko knjižničarstvo previše kasne za svjetskim

\footnotetext{
50 Usp. React native: Learn once, write anywhere. [citirano: 2021-01-15]. Dostupno na: https:// reactnative.dev.

${ }^{51}$ Buzet, Rovinj, Vinkovci, Pazin, Pakrac, Križevci, Buje, Umag, Kaštela, Osijek, Biograd na Moru, Samobor, Virovitica, Virje i Bjelovar.
} 
trendovima te da, u vrijeme kada u svijetu postoji više od 4 milijuna aplikacija, ${ }^{52}$ svega nekolicina spomenutih aplikacija na hrvatskom tržištu nije dovoljna da bi zadovoljila potrebe naših korisnika, a niti je njihova pokrivenost u knjižnicama zadovoljavajuća.

Razlog tome preveliko je oslanjanje na pružatelje programskih rješenja za poslovanje knjižnica i očekivanje rješenja s njihove strane. Kao i u hrvatskim knjižnicama kojima manjka knjižničara i financijske stabilnosti, ista je situacija i kod pružatelja programskih rješenja te oni ne mogu pravodobno reagirati na sve novosti i mogućnosti. Potrebna je veća otvorenost prema gotovim inozemnim ili nacionalnim rješenjima koja su dostupna ili ih treba razviti kako bi se ubrzao proces pružanja kvalitetnih i novih usluga knjižničnim korisnicima jer je konkurencija knjižnicama u popunjavanju obrazovnih potreba, ali i slobodnog vremena korisnika svakim danom sve jača.

Knjižnice postoje radi svojih korisnika te svoje usluge moraju pravovremeno prilagođavati njihovim potrebama. Korisničke potrebe individualne su bili korisnici funkcionalno pismeni, nepismeni, informatički pismeni ili informatički nepismeni. Ljudi koriste knjižnice iz raznih razloga i za razne potrebe, a obaveza je i imperativ knjižničarima pokušati odgovoriti na sve njih. Svaka knjižnica prepoznaje potrebe zajednice u kojoj djeluje, ali postoje univerzalne potrebe korisnika koje se pojavljuju širom svijeta - ponuda aplikacija našim korisnicima jedna je od njih i smjer kojim se hrvatsko knjižničarstvo treba više baviti kako bismo u današnje brzo i elektroničko doba zauzeli svoje mjesto u svakodnevnom životu korisnika. No pri tome ne bi se trebalo odlučivati za bilo kakvo rješenje, već ustrajati na zagovaranju kvalitete te koristiti inozemna i domaća istraživanja i iskustva.

\section{LITERATURA}

Advent in Zagreb. // Google Play. [citirano: 2021-01-15]. Dostupno na: https://play.google.com/store/apps/details?id=com.pozdravizzagrebagmail.greetingsfromzagreb\&hl=en.

Beletrina. [citirano: 2021-01-15]. Dostupno na: https://beletrina.si.

Biblos2. // Apple Store. [citirano: 2021-01-15]. Dostupno na: https://apps.apple.com/hr/app/biblos2/id1241880218.

Biblos2. // Google Play. [citirano: 2021-01-15]. Dostupno na: https://play.google.com/store/apps/details?id=com.artatech.biblosReader\&hl=hr.

52 Usp. Iqbal, M. App download and usage statistics (2020). [citirano: 2021-01-15]. Dostupno na: https://www.businessofapps.com/data/app-statistics. 
British Library launches first smartphone app. [citirano: 2021-01-15]. Dostupno na: https://www.bl.uk/press-releases/2011/january/british-library-launches-first-smartphone-app\#.

Clement, J. Share of global mobile website traffic 2015-2020. // Statista, 28 April, 2021. [citirano: 2021-01-15]. Dostupno na: https://www.statista.com/statistics/277125/ share-of-website-traffic-coming-from-mobile-devices.

CSS tutorial. [citirano: 2021-01-15]. Dostupno na: https://www.w3schools.com/css.

DC Public Library launches first free library iPhone application in nation. // DC Public Library [citirano: 2021-01-15]. Dostupno na: https://www.dclibrary.org/node/574.

e-Iskaznica: Gradska knjižnica Poreč. // GooglePlay. [citirano: 2021-01-15]. Dostupno na: https://play.google.com/store/apps/details?id=hr.com.synet.eiskaznice\&hl=hr\&gl=US.

e-Iskaznica. // Apple Store. [citirano: 2021-01-15]. Dostupno na:

https://apps.apple.com/us/app/eiskaznica/id1579065835\#?platform=iphone

e-Iskaznica: Novi digitalni iskorak Gradske knjižnice Poreč. [citirano: 2021-01-15]. Dostupno na: https://www.knjiznicaporec.hr/e-usluge/e-iskaznica.

Hi! I'm Libby. [citirano: 2021-01-15]. Dostupno na: https://www.overdrive.com/apps/ libby.

How many smartphones are in the world? : January 2021 mobile user statistics: Discover the number of phones in the world \& smartphone penetration by country or region. [citirano: 2021-01-15]. Dostupno na: https://www.bankmycell.com/blog/ how-many-phones-are-in-the-world.

HTML: Living Standard. [citirano: 2021-01-15]. Dostupno na: https://www.w3.org/TR/html52/introduction.html\#background

Huawei AppGallery kao osnovna trgovina aplikacija? Upitali smo ih kako to funkcionira. [citirano: 2021-01-15]. Dostupno na: https://www.bug.hr/intervju/huawei-appgallery-kao-osnovna-trgovina-aplikacija-upitali-smo-ih-kako-to-15165.

iBiblos - posudba elektroničkih knjiga za korisnike GISKO-a. [citirano: 2021-01-15]. Dostupno na: https://www.gskos.unios.hr/index.php/ibiblos-posudba-elektronickih-knjiga-za-korisnike-gisko-a.

Iqbal, M. App download and usage statistics (2020). [citirano: 2021-01-15]. Dostupno na: https://www.businessofapps.com/data/app-statistics.

JavaScript. [citirano: 2021-01-15]. Dostupno na: https://developer.mozilla.org/en-US/ docs/Web/JavaScript.

Jesmo li ovisni? Više od polovice Hrvata nosi mobitel i u krevet. [citirano: 2021-0115]. Dostupno na: https://www.vecernji.hr/techsci/istrazivanje-mobitel-huawei-ipsos- 1224345 . 
Kerr, A.; D.R. Pennington. Public library mobile apps in Scotland: Views from the local authorities and the public. // Library Hi Tech 36, 2(2018), str. 237-251. DOI: 10.1108/LHT-05-2017-0091.

Klarin Zadravec, S.; D. Koljenik. Pozdrav iz Zagreba: Izložba. // Virtualne izložbe. [citirano: 2021-01-15]. Dostupno na: http://virtualna.nsk.hr/portfolio/pozdrav-iz-zagreba.

Kuda idu mobilne aplikacije?. [citirano: 2021-01-15]. Dostupno na: https://www.vecernji.hr/techsci/kuda-idu-mobilne-aplikacije-1347747.

Libby, by OverDrive. // Apple Store. [citirano: 2021-01-15]. Dostupno na: https://apps. apple.com/us/app/libby-by-overdrive/id1076402606.

Libby, by OverDrive.// Google Play. [citirano: 2021-01-15]. Dostupno na: https://play.google.com/store/apps/details?id=com.overdrive.mobile.android.libby\&hl=en\&gl=US.

Lukačić, P. Nativna aplikacija Knjižnica „Fran Galović““. // Svezak 22(2020), str. 11-13. [citirano: 2021-01-15]. Dostupno na:

http://www.drustvo-knjiznicara-bpkp.hr/svezak/svezak22/Svezak_22_2020.pdf.

Mansouri, A; N. A. Nooshin. Assessing mobile application components in providing library services. // The Electronic Library 37, 1(2019), str. 49-66. DOI: 10.1108/ EL-10-2018-0204.

mKnjižnica. [citirano: 2021-01-15]. Dostupno na: www.mknjiznica.com.

Mobile application. // Cambridge Dictionary. [citirano: 2021-01-15]. Dostupno na: https://dictionary.cambridge.org/dictionary/english/mobile-application.

Pew Research Center. Part 1: An introduction to the issues surrounding libraries and e-books. [citirano: 2021-01-15]. Dostupno na: https://www.pewresearch.org/internet/2012/06/22/part-1-an-introduction-to-the-issues-surrounding-libraries-and-ebooks.

Pew Research Center. Part 6: A Closer look at e-book borrowing: Overview of responses in our online panel. [citirano: 2021-01-15]. Dostupno na:

https://www.pewresearch.org/internet/2012/06/22/part-6-a-closer-look-at-e-book-borrowing/\#librarians-and-publishers.

Predstavljena prva digitalna platforma za posudbu e-knjiga u Istri. [citirano: 2021-0115]. Dostupno na: https://www.pula.hr/hr/novosti/detail/18413/predstavljena-prva-digitalna-platforma-za-posudbu-e-knjiga-u-istri.

Public library mobile app survey: January 2018. [citirano: 2021-01-15]. Dostupno na: https://s3.amazonaws.com/WebVault/research/2018_PublicLibraryMobileAppSurvey.pdf. 
Qualitative research into the provision and impact of ICT in public libraries in Sweden. [citirano: 2021-01-15]. Dostupno na:

https://digital.lib.washington.edu/researchworks/bitstream/handle/1773/24036/ TNS_Sweden_English.pdf?sequence=1.

React native - learn once, write anywhere. [citirano: 2021-01-15]. Dostupno na: https:// reactnative.dev.

Schwartz, M. Demco Buys Boopsie. [citirano: 2021-01-15]. Dostupno na: https://www. libraryjournal.com/?detailStory=demco-buys-boopsie.

Smart library NSK: Virtualni vodič kroz prostor i usluge Nacionalne i sveučilišne knjižnice u Zagrebu. [citirano: 2021-01-15]. Dostupno na: http://smart.nsk.hr.

Škoda, S. Knjižnica i čitaonica Fran Galović predstavila mobilnu aplikaciju, ravnatelj Galinec: Postajemo još dostupniji korisnicima. [citirano: 2021-01-15]. Dostupno na: https://drava.info/2019/12/knjiznica-i-citaonica-fran-galovic-mobilna-aplikacija.

The history of Android: The evolution of the biggest mobile OS in the world. [citirano: 2021-01-15]. Dostupno na: https://www.androidauthority.com/history-android-os-name-789433.

The History of Mobile Apps. [citirano: 2021-01-15]. Dostupno na: https://inventionland.com/inventing/the-history-of-mobile-apps.

Vollmer, T. There's an app for that! Libraries and mobile technology: An Introduction to public policy considerations. // Policy brief 3(2010), 1-14. [citirano: 2021-01-15]. Dostupno na: http:/www.ala.org/advocacy/sites/ala.org.advocacy/files/content/advleg/pp/pub/policy/mobiledevices.pdf.

Wang, C.; H. Ke; W. Lu. Design and performance evaluation of mobile web services in libraries: A Case study of the Oriental Institute of Technology Library. // The Electronic Library 30(2012), str. 33-50. DOI:10.1108/02640471211204051.

What is mobile application development? [citirano: 2021-01-15]. Dostupno na: https:// aws.amazon.com/mobile/mobile-application-development.

Wyatt Greg, Jr. History of iOS. Medium. [citirano: 2021-01-15]. Dostupno na: https:// gregwyattjr.medium.com/history-of-ios-b4948d4d7993.

Zagreb bogatiji za još jednu mobilnu aplikaciju - Pozdrav iz Zagreba. [citirano: 202101-15]. Dostupno na: https://www.nacional.hr/zagreb-bogatiji-za-jos-jednu-mobilnu-aplikaciju-pozdrav-iz-zagreba.

ZaKi Book. // Apple Store. [citirano: 2021-01-15]. Dostupno na: https://apps.apple.com/hr/app/zaki-book/id1464530319.

ZaKi Book. // Google Play. [citirano: 2021-01-15]. Dostupno na: https://play.google.com/store/apps/details? $\mathrm{id}=\mathrm{io}$. cordova.zakibook\&hl=hr. 